\title{
FEATURES OF VALUE-MOTIVATIONAL SPHERE OF LAW ENFORCERS IN THE PERIOD OF THE CRISISOF PROFESSIONAL FORMATION
}

https://doi.org/10.37096/SHDISJ-19-1.1-0006

\author{
Pomytkina Lubov, \\ https://orcid.org/0000-0002-2148-9728 \\ Polukhina Maryna \\ https://orcid.org/0000-0001-6534-3635
}

\begin{abstract}
The purpose of the article is to highlight the results of the theoretical and empirical study of the peculiarities of manifestation of the value-motivational sphere of law enforcers in the period of the crisis of professional formation. To achieve the goal, a theoretical analysis of scientific literature was carried out, which showed that the crisis of professional formation of law enforcers of early adulthood is a psychological phenomenon that arises in a situation where the person does not have enough means to effectively overcome the difficulties of professional development, caused by violations of the process of adaptation, needs, inconsistency between the desirable and actual reality. Empirical study was conducted by the valid psychodiagnostic methods "Diagnosis of motivators of social and psychological activity of personality" by D. McClelland, "Self-actualization test" ofYu. Aleshina, L. Gozman and methods of mathematical statistics: t-criterion of the Student, U-criterion of Mann Whitney. The study was attended by employees of the Main Directorate of the National Police of Ukraine in Kyiv, consisting of 139 people.
\end{abstract}

An empirical study showed that the level of manifestation of the crisis of professional formation among law enforcers aged $23-28$ years is average (in $47.22 \%$ of persons) and high (36.11\% of persons); among law enforcers aged 35-43 years, the low level of the crisis of professional formation prevails $(61,20 \%)$, which indicates the formation of adaptive mechanisms of personality. The peculiarities of the value-motivational sphere include: the existence of an overreliant need for achieving success and belonging to the group; time orientation difficulties; idealistic ideas about human nature; flexibility of behavior; increased level of contact and sensitivity; developed cognitive needs; low level of self-esteem, self-acceptance and support. enforcers.

Keywords: motivation, values, crises, crisis of professional formation, personality, law

\section{Introduction}

The rapid pace of life of modern society, the peculiarities of the political and economic situation, the need to meet modern requirements for personality and professional formation, cause the emergence of internal conflicts, strain, destruction of own perceptions about values and ideals,and leads to a crisis of professional formation of the personality. This problem is particularly acute for those whose duty is to protect the Motherland and its citizens.

The crisis of professional formation of law enforcement officersis caused by the direct connection with efficiency oftheir professional activities. The experience of the crisis by law enforcers leads, on the one hand, to acute and chronic psychogenic emotional states, and on the other hand, to reduction of the effectiveness of the law enforcement activity, its productivity, reliability, and as a result, can become a reason for violation of legality in the performance of official duties or become a precondition for the professional deformation of personality, suicide etc.

To research of the problems of psychological components of service activity and correction of the crisis of professional formation of law enforcement officers has been devoted the attention of such scholarsas B.Baranenko, D.Babichev, V. Krivolapchuk (Baranenko, Babichev, Krivolapchuk, 2012), V. Barco (Barko, 2002), E. Simaniuk (Simanyuk, 2004).

Researchers define professional formation as an important component of the personality's life, and the crisis as an integral part of this process. However, the given analysis of scientific sources makes it possible to conclude that there is a shortage of theoretical and practical research on this issue. The crisis of professional formation is considered a complicated psychological phenomenon, which manifests itself in many areas of life activity of the individual. In particular, the 
greatest manifestation of the crisis depends on the values embodied in the personality and the motivation formed on their basis (Polukhina, 2017: 145-149; Polukhina, 2017: 213-216).

The purpose of the article is to study the peculiarities of the manifestation of the valuemotivational sphere of law enforcers in the period of the crisis of professional formation in early adulthood.

The psychological phenomenon of the crisis was researched by foreign (S. Vinnet, 2003, B. Levehud, 1994, M. Sieger, 1998, G. Shihi, 1999, etc.), and domestic scientists (F.Vasilyuk, 1984, Ye. Zeyer, 2007, A.Kokun, 2012, L.Pergamenshchik, 2004, L. Pomytkina, 2017, Ye. Simanjuk, 2004, L. Sokhan, 1998, T.Titarenko, 2004, etc.).

In particular, S. Vinett and M. Sieger investigated the crisis as a process of transformation of the old system, which can no longer be self-organized and manageable (Seeger,1998: 231-275; Venette, 2003), pointed to the need for change as another sign of the crisis; known psychotherapist B. Levehud considered the problem of the crisis of professional formation as a part of the life crisis, that is, the transition to a new state, he saw the source of a newdevelopment of a human and the life path of a human in three aspects: biological, psychological and spiritual (Livehud, 1994); as G. Shih notes, in times of crisis moments, the way of life undergoes sudden changes in four dimensions: the inner sense of oneself with respect to others; feeling of safety and danger; transience of time; a sense of physical decline - they all set the basic tone of life and push people to one or other decisions (Shihi, 1999).

According to E. Zeyer, the crises of professional formation are manifested in the variable orientation of the professional development of the person and cause the transformation of psychological structure of the personality. Formation of personality, according to the scientist's definition, necessarily requires the need for development, self-development, and professional self-preservation (Zeer, 2007: 29, 58); researcher L. Sohan with a group of colleagues and like-minded people deeply analyzed the life crisis of the personality, considering them throughout the life path of a human (Doniy, Gesen, Sohan, Ermakov, 1998); T. Titarenko not only theoretically studied, but also developeda psychological support of the personality while experiencing the crisis (Titarenko, 2004); also F. Vasilyuk explored the peculiarities of the human's feelings during the deployment of the crisis (Vasilyuk, 1984), which he defines asa long internal conflict regarding life, its meaning, main goals and the ways of achieving them.

Modern researcher O.Kokun, considering the process of formation of the personality of a specialist from the beginning of the choice of profession and to the end of labor activity, has generalized the features of groups of psychological crises (Kokun, 2012: 8; 14); E.Simanukhas defined two main types of crises: 1) crisis, caused by occasional random events that violate the trajectory of professional development (firing from a job, retraining, change of residence, breaks in worketc); 2) the crisis of self-actualization (an excessive crisis of professional formation) (Simanyuk, 2004: 29); L. Pergamenshchik defines the crisis as a situation of emotional and mental stress, which requires a change in the perceptions of the world and oneself in a short period of time and entails a change in the structure of the personality, which can gain both positive and negative character (Pergamenchik, 2004); L. Pomytkina researched the manifestations of the crisis during the decision-making by specialists in special conditions of activity (Pomytkina, 2017: 228-232; Pomytkina, 2016: 107-116).

So, analyzing the psychological content of the crisis of professional formation and its peculiarities, scientists and researchers came to the conclusion that in this period a person undergoes a process of transformation of the old system of values which is perceived as a "test time" and an "extraordinary event" that has the signs: unexpectedness, the need for change, uncertainty; as a turning point in the normal course of mental development; chain of internal human changes; as a situation of emotional and mental stress, which requires a change in the perceptions of the world and oneself and entails changes in the structure of the personality, which can be both positive and negative; like any sudden interruption of the normal course of events in life, which requires a reappraisal of the models of activity and thinking; as a process of experiencing (Polukhina ,2017: 145149; Polukhina, 2017: 213-216).

Thus, the crisis of the professional formation of law enforcers of early adulthood is determined by us as a psychological phenomenon that arises in a situation when the personality has not enough 
means to effectively overcome the difficulties of professional development due to violations of the process of adaptation, needs, inconsistency between desired and actual reality. The structural components of the crisis of professional formation of law enforcersof the age of early adulthood include cognitive, emotional, behavioral, individual-typological and value-motivational. As one of the most important, value-motivational is based on awareness of the social significance of professional activity and personal responsibility for its results, the need for professional selfimprovement, achievement of success, availability of value orientations, etc.

Under the condition of constructive resolution of the crisis, there must be a reformation of the psychological structure of the personality, a change in the social and professional orientation, the professional development is encouraged, as a result of which the personality goes up to a higher level of development.

An empirical study was conducted to determine the peculiarities of manifestation of the value-motivational sphere of lawenforcers in the period of the crisis of professional formation in early adulthood.

\section{Methodology}

The study was attended by employees of the Main Directorate of the National Police of Ukraine in Kyiv, consisting of 139 people: 72 respondents aged 23-28 (early adolescence) who had experience working in law enforcement bodies for a maximum of 3 years; the second group - 67 people aged 35-43 (middle adolescence) with work experience of more than 10 years.

Methodological basis of the research was the theory of motivation of D. McClelland, which shows the most important among the "secondary needs", which are analyzed, if the material welfare is satisfiedenough. He claimed that any organization givesto employee the ability of realization of the three highest-level needs: power, success, and affiliation, however, different people expressthese needs differently or exist in certain combinations. The specificity of their combination depends on the natural qualities, personal experience, human culture, etc. So, for the investigation of law enforcers, the methodology "Diagnostics of the motivators of social and psychological activity of the personality" (D. McClelland) was used.

\section{Results}

Value-motivational sphere of law enforcers was investigated using the method "Selfactualization test" (SAT) by (Yu. Alyoshina, L. Gozman), which allowed to define the indicators that comprehensively reveal the valuemotivational component of the crisis' experience. The distribution of the indicators by this method is shown in Table 1 (see next page below).

According to Table 1, respondents aged 23-28 have a low level of orientation in time (51.39\%), indicating that they are unable to live completely in the present moment ("here and now"), they are aggravated by reflections on the past and worries about the future, as opposed to the second group, which demonstrated a generally high level of orientation in time, that is, the ability to direct the resources on the current life and give it greater advantage than the past and the future. According to the indicator of support among young respondents, there is a lack of self-support skills (56.94\%), which may result in dependence on external support. The value orientation indicator in both groups is low (group $1-43.06 \%$, group 2 $25.37 \%$ ) and the average level (group 1 - 22.22\%, group $2-25.37 \%$ ), indicating the desire of young people to show themselves on the best hand as highly moral personalities, or the presence of such features as idealism and maximalism. Representatives of the second group have already managed to form a balanced and stable system of their own values.

Young employees have a flexible behavior, which indicates the ability to adjust to external circumstances and respond quickly to changes in the environment, adapting to it. A slightly different situation with the respondents of the second group, who already have a prevailing system of values, ideas about oneself, etc.

According to the sensitivity indicator, both groups show low results (group $1-51.39 \%$, group 2 - 76.12\%). As known, for the service in law enforcement bodies are selected physically and psychologically strong and hard-working employees, who show resistance and courage. Because of this, sensitivity and sensibilitycannot be too high. However, the first group has more respondents with high sensitivity (26.39\%), indicating the ability to remain more sensitive to the feelings. 
Spontaneity is not typical for this sample, both groups showed low results.

Respondents aged 23-28 have generally low (65.28\%) and average results (18.06\%), however, among them, more respondents are characterized by spontaneity,

ability to unexpected decisions and actions (16.67\%).

Table 1

Distribution of self-actualization indicators among law enforcers, $n=139$

\begin{tabular}{|c|c|c|c|c|c|c|c|c|}
\hline \multirow[t]{3}{*}{ Level of manifestation } & \multicolumn{8}{|c|}{ Respondents, \% (persons) } \\
\hline & $\frac{\bar{d}}{\frac{\vec{d}}{3}}$ & 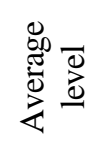 & 矛 & 总 & 胥 & 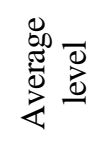 & 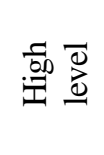 & 密 \\
\hline & \multicolumn{4}{|c|}{1 group } & \multicolumn{4}{|c|}{2 group } \\
\hline Time orientation & $\begin{array}{c}51,39 \\
(37)\end{array}$ & $\begin{array}{c}15,28 \\
(11)\end{array}$ & $\begin{array}{c}33,33 \\
(24)\end{array}$ & $\begin{array}{c}0 \\
(0)\end{array}$ & $\begin{array}{c}8,96 \\
(6)\end{array}$ & $\begin{array}{c}17,91 \\
(12)\end{array}$ & $\begin{array}{c}46,27 \\
(31)\end{array}$ & $\begin{array}{c}26,87 \\
(18)\end{array}$ \\
\hline Support & $\begin{array}{c}56,94 \\
(41)\end{array}$ & $\begin{array}{c}18,06 \\
(13)\end{array}$ & $\begin{array}{l}25,0 \\
(18)\end{array}$ & $\begin{array}{c}0 \\
(0) \\
\end{array}$ & $\begin{array}{c}17,91 \\
(12)\end{array}$ & $\begin{array}{c}22,39 \\
(15)\end{array}$ & $\begin{array}{c}38,81 \\
(26)\end{array}$ & $\begin{array}{l}20,9 \\
(14)\end{array}$ \\
\hline Value orientation & $\begin{array}{c}43,06 \\
(31)\end{array}$ & $\begin{array}{c}22,22 \\
(16)\end{array}$ & $\begin{array}{c}30,56 \\
(22)\end{array}$ & $\begin{array}{r}4,17 \\
\text { (3) }\end{array}$ & $\begin{array}{l}40,3 \\
(27) \\
\end{array}$ & $\begin{array}{c}25,37 \\
(17) \\
\end{array}$ & $\begin{array}{c}34,33 \\
(23)\end{array}$ & $\begin{array}{c}0 \\
(0)\end{array}$ \\
\hline Flexibility of behavior & $\begin{array}{c}15,28 \\
(11)\end{array}$ & $\begin{array}{c}15,28 \\
(11)\end{array}$ & $\begin{array}{c}55,56 \\
(40)\end{array}$ & $\begin{array}{c}13,89 \\
(10)\end{array}$ & $\begin{array}{c}55,22 \\
(37)\end{array}$ & $\begin{array}{c}32,84 \\
(22)\end{array}$ & $\begin{array}{c}11,94 \\
(8)\end{array}$ & $\begin{array}{c}0 \\
(0)\end{array}$ \\
\hline Sensitivity & $\begin{array}{c}51,39 \\
(37) \\
\end{array}$ & $\begin{array}{c}19,44 \\
(14)\end{array}$ & $\begin{array}{c}26,39 \\
(19) \\
\end{array}$ & $\begin{array}{c}2,78 \\
(2)\end{array}$ & $\begin{array}{c}76,12 \\
(51) \\
\end{array}$ & $\begin{array}{l}20,9 \\
(14) \\
\end{array}$ & $\begin{array}{c}2,99 \\
(2)\end{array}$ & $\begin{array}{c}0 \\
(0)\end{array}$ \\
\hline Spontaneity & $\begin{array}{c}65,28 \\
(47)\end{array}$ & $\begin{array}{c}18,06 \\
(13)\end{array}$ & $\begin{array}{c}16,67 \\
(12)\end{array}$ & $\begin{array}{c}0 \\
(0)\end{array}$ & $\begin{array}{l}79,1 \\
(53)\end{array}$ & $\begin{array}{c}7,46 \\
(5)\end{array}$ & $\begin{array}{c}13,43 \\
(9)\end{array}$ & $\begin{array}{c}0 \\
(0)\end{array}$ \\
\hline Self-esteem & $\begin{array}{l}37,5 \\
(27)\end{array}$ & $\begin{array}{c}27,78 \\
(20)\end{array}$ & $\begin{array}{c}33,33 \\
(24)\end{array}$ & $\begin{array}{c}1,39 \\
(1)\end{array}$ & $\begin{array}{c}11,94 \\
(8)\end{array}$ & $\begin{array}{c}23,88 \\
(16)\end{array}$ & $\begin{array}{c}49,25 \\
(33)\end{array}$ & $\begin{array}{c}14,93 \\
(10)\end{array}$ \\
\hline Self-perception & $\begin{array}{l}50,0 \\
(36)\end{array}$ & $\begin{array}{c}19,44 \\
(14)\end{array}$ & $\begin{array}{c}30,56 \\
(22)\end{array}$ & $\begin{array}{c}0 \\
(0)\end{array}$ & $\begin{array}{c}7,46 \\
(5)\end{array}$ & $\begin{array}{c}5,97 \\
\text { (4) }\end{array}$ & $\begin{array}{c}68,66 \\
(46)\end{array}$ & $\begin{array}{c}17,91 \\
(12)\end{array}$ \\
\hline An idea of the human nature & $\begin{array}{c}36,11 \\
(26)\end{array}$ & $\begin{array}{c}22,22 \\
(16)\end{array}$ & $\begin{array}{c}36,11 \\
(26)\end{array}$ & $\begin{array}{c}5,56 \\
(4)\end{array}$ & $\begin{array}{c}82,09 \\
(55)\end{array}$ & $\begin{array}{c}11,94 \\
(8)\end{array}$ & $\begin{array}{c}5,97 \\
(4)\end{array}$ & $\begin{array}{c}0 \\
0 \\
(0)\end{array}$ \\
\hline Synergy & $\begin{array}{c}58,33 \\
(42) \\
\end{array}$ & $\begin{array}{c}22,22 \\
(16)\end{array}$ & $\begin{array}{c}19,44 \\
(14)\end{array}$ & $\begin{array}{c}0 \\
(0)\end{array}$ & $\begin{array}{c}65,67 \\
(44) \\
\end{array}$ & $\begin{array}{c}8,96 \\
(6)\end{array}$ & $\begin{array}{c}25,37 \\
(17) \\
\end{array}$ & $\begin{array}{c}0 \\
(0)\end{array}$ \\
\hline Acceptance of aggression & $\begin{array}{c}59,72 \\
(43)\end{array}$ & $\begin{array}{c}29,17 \\
(21)\end{array}$ & $\begin{array}{c}11,11 \\
(8)\end{array}$ & $\begin{array}{c}0 \\
(0)\end{array}$ & $\begin{array}{c}47,76 \\
(32)\end{array}$ & $\begin{array}{c}26,87 \\
(18)\end{array}$ & $\begin{array}{c}23,88 \\
(16)\end{array}$ & $\begin{array}{c}1,49 \\
(1)\end{array}$ \\
\hline Contact & $\begin{array}{c}30,56 \\
(22)\end{array}$ & $\begin{array}{c}18,06 \\
(13) \\
\end{array}$ & $\begin{array}{c}44,44 \\
(32) \\
\end{array}$ & $\begin{array}{c}6,94 \\
(5)\end{array}$ & $\begin{array}{l}80,6 \\
(54) \\
\end{array}$ & $\begin{array}{c}16,42 \\
(11)\end{array}$ & $\begin{array}{c}2,99 \\
(2)\end{array}$ & $\begin{array}{c}0 \\
(0) \\
\end{array}$ \\
\hline Cognitive needs & $\begin{array}{c}23,61 \\
(17) \\
\end{array}$ & $\begin{array}{c}18,06 \\
(13) \\
\end{array}$ & $\begin{array}{l}50,0 \\
(36) \\
\end{array}$ & $\begin{array}{r}8,33 \\
(6) \\
\end{array}$ & $\begin{array}{c}86,57 \\
(58) \\
\end{array}$ & $\begin{array}{c}10,45 \\
(7)\end{array}$ & $\begin{array}{c}2,99 \\
(2)\end{array}$ & $\begin{array}{c}0 \\
(0) \\
\end{array}$ \\
\hline Creativity & $\begin{array}{c}88,89 \\
(64)\end{array}$ & $\begin{array}{c}11,11 \\
(8)\end{array}$ & $\begin{array}{c}0 \\
(0)\end{array}$ & $\begin{array}{c}0 \\
(0)\end{array}$ & $\begin{array}{c}82,09 \\
(55)\end{array}$ & $\begin{array}{c}14,93 \\
(10)\end{array}$ & $\begin{array}{c}2,99 \\
(2)\end{array}$ & $\begin{array}{c}0 \\
(0)\end{array}$ \\
\hline
\end{tabular}

Respondents of the second group are characterized by a high level of self-esteem (49.25\%), they respect their own personality and are inclined to take into account their own interests and needs. Young law enforcers have shown a low level of self-esteem (37.5\%) and self-acceptance (50.0\%), which may be due to a lack of success in self-realization, a desire for perfect ideas about oneself and the consequence of a crisis of professional development. However, respondents of the early adulthood are characterized by the desire for the ideal image of I, which is reflected in the indicator of the concept of human nature.
They are inclined to evaluate people, rather, as good and high moral, that means there is a tendency towards idealization, as opposed to respondents of middle age. The indicator of the idea of the human nature is closely linked to the next indicator - synergy. The results for both groups are the same: low (group $1-58.33 \%$, group 2 - 65.67\%). As known, synergy reflects the ability of the personalityfor integrated perception of phenomena, the search for interconnections. That is, respondents at a low level are able to see these connections (for example, the unity of physical and spiritual in a person), as well as see the 
connections between differences (eg, work and game).

As can be seen from the tables, young law enforcers have higher indicators of contact, which says about the desire to establish new and support the existing contacts with others. In addition, extremely relevant for themare the cognitive needs, which are realized through the acquisition of new information, studying and are directly related to the process of mastering the profession. The level of creativity is quite low in both groups (group 1 - 88.89\%, group 2 - 82.09\%), which indicates a low ability to creativity, creating something new, extraordinary, search for unusual new solutions. The work of the law enforcement officer is important, it does not stimulate the creative development, but is clear and strictly regulated.

Let us interpret the indicators obtained by the methodology "Diagnosis of the motivators of socio-psychological activity of personality" D. McClelland (Table 2).

Table 2

Distribution of indicators of needs-motivators of respondents, $n=139$

\begin{tabular}{|c|c|c|c|c|c|c|}
\hline \multirow{3}{*}{ Indicators } & \multicolumn{6}{|c|}{ Respondents, \% (persons) } \\
\hline & $\begin{array}{l}\text { Low } \\
\text { level }\end{array}$ & $\begin{array}{c}\text { Average } \\
\text { level }\end{array}$ & $\begin{array}{l}\text { High } \\
\text { level }\end{array}$ & $\begin{array}{l}\text { Low } \\
\text { level }\end{array}$ & $\begin{array}{c}\text { Average } \\
\text { level }\end{array}$ & $\begin{array}{l}\text { High } \\
\text { level }\end{array}$ \\
\hline & \multicolumn{3}{|c|}{1 group } & \multicolumn{3}{|c|}{2 group } \\
\hline Need for power & $\begin{array}{c}4,17 \\
(3)\end{array}$ & $\begin{array}{l}87,5 \\
(63)\end{array}$ & $\begin{array}{c}8,33 \\
(6)\end{array}$ & $\begin{array}{r}1,49 \\
(1) \\
\end{array}$ & $\begin{array}{c}55,22 \\
\text { (37) }\end{array}$ & $\begin{array}{c}43,28 \\
(29)\end{array}$ \\
\hline Need for success & $\begin{array}{c}2,78 \\
(2)\end{array}$ & $\begin{array}{c}51,39 \\
(37)\end{array}$ & $\begin{array}{c}45,83 \\
\text { (33) }\end{array}$ & $\begin{array}{c}1,49 \\
(1)\end{array}$ & $\begin{array}{c}52,24 \\
(35)\end{array}$ & $\begin{array}{c}46,27 \\
(31)\end{array}$ \\
\hline Need for affiliation & $\begin{array}{c}6,94 \\
(5)\end{array}$ & $\begin{array}{c}61,11 \\
(44)\end{array}$ & $\begin{array}{c}31,94 \\
(23)\end{array}$ & $\begin{array}{c}1,49 \\
(1)\end{array}$ & $\begin{array}{c}91,04 \\
(61)\end{array}$ & $\begin{array}{c}7,46 \\
\text { (5) }\end{array}$ \\
\hline
\end{tabular}

According to Table 2, among the motivators of social and psychological activity of both groups, the need for success is prevailing. Respondents aged 23-28 showed an average level of performance of all indicators, meaning that these needs are relevant, but not dominant. For law enforcers aged 35-43, there is a high and average level of need for power and success, however, the need for affiliation loses its expediency. It is worth noting that the need for achieving success is particularly acute when it comes to the so-called "special conditions of activity", to which the service in law enforcement agenciesbelongs. It is known that the maximum age of service in power agencies is 20-25 years. Under such conditions and in such short period of professional activity, it is needed to master the specifics of a profession, achieve a certain career growth, credibility, climb up the service steps (get a higher position, rank, salary, etc.). Thus, one of the key aspects of the motive for success is the need, within a short period of time, to achieve significant professional growth, the absence of which will result in retirement from a small post, which results in insufficient pension (material) provision.
Consequently, the results showed an extreme need for success $(45.83 \%)$ and unity with the group (32.0\%of the respondents), as well as a low level of value orientation (43.0\%) among respondents. The majority of respondents aged 2328 have an average (47.22\% of persons) and a high (36.11\% of persons) levelsofmanifestation of the crisis of professional development. They have high levels of anxiety, internal conflict, social frustration, sensitivity, and so on. Instead, a low level of reflexivity, self-worth, behavioral selfregulation, underdeveloped adaptive and communicative potential, etc. Law-enforcers aged 35-43 have the prevailedlow level of the crisis of professional development (61,20\%), which indicates the formation of adaptive mechanisms of personality.

To identify the features of the manifestation of the characteristics of the value-motivational component and in order to establish statistical differences between the indicators of selfactualization (Table 3), we applied the t-criterion of the Student; differences between indicators of needs-motivators (Table 4) - U-criterion of MannWhitney. 
Table 3

Comparative statistical analysis of indicators of the value-motivational component (by SAT methodology), $n=139$

\begin{tabular}{|l|c|c|c|}
\hline \multirow{2}{*}{$\begin{array}{c}\text { Statistic alanalysis method: } \\
\text { Criterion of the Student }\end{array}$} & \multicolumn{2}{c|}{ Groups } & \multirow{2}{*}{ Significance } \\
\cline { 2 - 3 } & $\mathbf{1}(\mathrm{n}=72)$ & $\mathbf{2}(\mathrm{n}=67)$ & \\
\hline Target in time & $48,98 \pm 15,77$ & $67,50 \pm 17,57$ & 0,001 \\
\hline Support & $45,39 \pm 14,22$ & $62,80 \pm 18,25$ & 0,001 \\
\hline Flexibilityofbehavior & $61,77 \pm 15,86$ & $42,67 \pm 13,16$ & 0,001 \\
\hline Sensitivity & $45,76 \pm 17,09$ & $32,92 \pm 13,88$ & 0,001 \\
\hline Self-esteem & $49,72 \pm 14,23$ & $63,79 \pm 14,46$ & 0,001 \\
\hline Self-perception & $48,69 \pm 12,18$ & $67,94 \pm 13,57$ & 0,001 \\
\hline An idea about the human nature & $53,37 \pm 16,40$ & $34,82 \pm 13,89$ & 0,001 \\
\hline Contact & $55,90 \pm 17,76$ & $33,53 \pm 13,53$ & 0,001 \\
\hline Cognitive needs & $58,39 \pm 16,78$ & $30,71 \pm 12,74$ & 0,001 \\
\hline
\end{tabular}

According to the data obtained, significant differences between the groups were detected in 9 indicators. Respondents aged 23-28 turned out to be less oriented in time, due, in the first place, to the crisis of professional development, since the first group is now more forward-looking, focused on development in the profession, unlike the age group of 35-43, which has already achieved a certain level of self-realization.

According to the indicators of support, selfesteem and self-perception, the first group also has considerably lower results: they have worse attitude towards themselves, they are less inclined to accept and respect themselves, they don't know how or don't consider it necessary to provide support to themselves, etc. These features are related to the crisis of professional development. The difficult period of adaptation often brings a lot of failures and makes feel disappointedin oneself. The desire for quick professional formation and professionalism forms idealistic ideas about the profession and its representatives, and the discrepancy between the current state of things increases self-denial and reduces respect for oneself.

In this case, the sensitivity indicator of young people is much higher which results the increased sensitivity to external circumstances. Young law enforcers have an adaptive potential that manifests itself in high indicators of flexibility of behavior, contacts and cognitive needs. That is, respondents from the first group canadjust their behavior better under requirements of circumstances, are able to provide productive interaction with others and have a desirefor development in chosen profession, which indicates the ability to successfully pass the crisis of professional formation.

Differences between indicators of needsmotivators in two groups of law enforcers.

Table 4

\section{Comparative statistical analysis of indicators of value-motivational component} (by D. McClelland's method), $n=139$

\begin{tabular}{|c|c|c|c|}
\hline \multirow{2}{*}{$\begin{array}{c}\text { Method of statistical analysis: } \\
\text { Mann-Whitney's criterion }\end{array}$} & \multirow{2}{*}{ Significance } & \multicolumn{2}{|c|}{ Groups } \\
\cline { 2 - 4 } & & $\mathbf{1}(\mathrm{n}=72)$ & $\mathbf{2}(\mathrm{n}=67)$ \\
\hline \multirow{2}{*}{ The need for power } & Indicator of significance & \multicolumn{2}{|c|}{0,001} \\
\cline { 2 - 4 } & Average rank & 52,56 & 88,74 \\
\hline The need for affiliation & Indicator of significance & \multicolumn{2}{|c|}{0,001} \\
\cline { 2 - 4 } & Average rank & 83,24 & 53,77 \\
\hline
\end{tabular}

According to Table 4, significant differences between the two groups of respondents were identified by indicators of the need for power and affiliation. While success is aimed at both young and experienced workers, according to the motivators of socio-psychological activity, the results are almost the opposite. For experienced workers (group 2), the need for power comes in 
first place, due to the fact that professional growth in the system of law enforcement bodies tends to be manifested in obtaining higher ranks and positions. That is, career growth is identical to the increase of power in this profession. The need for affiliation is extremely relevant for young professionals: they are uncertain about professional adaptation and need external support, as opposed to respondents aged 35-43.

So, the results of the empirical study showed an extremelevel of need for success (45.83\%) and unity with the group (32.0\%), as well as a low level of value orientation (43.0\%) of respondents. Most respondents aged $23-28$ have an average (47.22\% of persons) and high (36.11\% of persons) levels of manifestationof the crisis of professional formation. In law enforcers aged 35-43, the low level of the crisis of professional formation prevails $(61,20 \%)$, which indicates the formation of adaptive mechanisms of personality.

\section{Discussion}

The data obtained by us in general do not contradict the characteristics of the crisis phenomena in the value-motivational sphere of the personality specified by scientists and researchers, whose works were analyzed by us in the theoretical part. The existence of a crisis of professional formation of law enforcers, as stated by us, requires special attention from the leaders of these enforcement bodies, and the development and implementation of both organizational and psychological methods of correction of this phenomenon. Organization of work on psychological support of the process of overcoming the psychological difficulties of the professional formation of young law enforcers requires agreed, coordinated actions of all subjects: the head, mentor, psychologist, staffing apparatus.

We believe that the issue of stabilization of the personnel and the consolidation of young employees should be one of the priorities that are currently facing law enforcement agencies, since the mission of solving the entire arsenal of tasks assigned to the law enforcement bodies to ensure the law order and security, as well as strengtheningthe prestige and authority of law enforcement bodies in society, depends on the level of professionalism and competence of their employees.

Thus, the obtained data indicated the necessity of providing psychological assistance to overcome the crisis of professional formation of law enforcers of early adulthood with a high and average level of manifestation of the crisis of professional formation, as well as the need to develop and implement a differential model of correction-development program to overcome the crisis of professional formation that will be presented in the next publications.

\section{Conclusion}

Determinant factors of the emergence of the crisis of professional formation of law enforcers of the early adulthood are defined: difficulties of professional adaptation, differences of professional expectations and reality; dissatisfaction with oneself and own professional status, the need for further professional development; the revision of own I-concept, the restructuring of socio-professional values and relationships, the need for self-determination and self-organization; socio-economic conditions; transition to a new post, certification, obtaining another rank; absorption by professional activity; age psychophysiological changes; service specificity; gender stereotypes, etc.

An empirical study has shown that the level of manifestation of the crisis of professional formation among law-enforcers aged 23-28 years is average (in $47.22 \%$ of persons) and a high (36.11\% of persons). Law enforcers aged 35-43, have low level of the crisis of professional formation prevailed $(61,20 \%)$, which indicates the formation of adaptive mechanisms of personality.

The peculiarities of the value-motivational component of the crisis of professional formation of law enforcers in early adulthood include: the existence of an extreme need for achieving success and belonging to the group; time orientation difficulties; idealistic ideas about human nature; flexibility of behavior; extreme level of contact and sensitivity; developed cognitive needs; low level of self-esteem, self-acceptance and support.

In future publications, we plan to highlight the study of the peculiarities of the manifestation of other components of the crisis of professional formation of law enforcers in early adulthood, as well as correctional measures to overcome the crisis of professional formation.

Conflict of interest. We state that there is no conflict of scientific interests.

\section{References}

Barko, V. I. (2002). Profesiinyi vidbir kadriv do orhaniv vnutrishnikh sprav ( psykholohichnyi 
aspekt) [Professional selection of personnel to the bodies of internal affairs (psychological aspect)] . Kiev: Nika-Senter. [in Ukrainian]

Vasilyuk, F. E. (1984). Psikhologiia perezhivaniia (analiz preodoleniia kriticheskikh situatsii) [Psychology of experience (analysis of overcoming critical situations)]. Moskva: Izdvo Mosk. Un-ta. [in Russian]

Doniy, V. M., Gesen G. N., Sohan, L. V., Ermakov I. G. (Red.) (1998). Zhyttievi kryzy osobystosti: Nauk.-metod. posibnyk [Life Crises of Personality: Psychology of Life Crises of Personality]. (P. 1). Kiev: IZMN. [in Ukrainian]

Zeer, E. F. (2007). Psikhologiia professionalnogo razvitiia [Psychology of Professional Development]. (2nd ed.). Moscow: Publishing Center "Academiya” [in Russian]

Kokun, O. M. (2012). Psykholohiia profesiinoho stanovlennia suchasnoho fakhivtsia [Psychology of the professional formation of a modern specialist]. Kiev: DP «Inform analyst the agency». [in Ukrainian]

Livehud, B. (1994). Crises of life - the odds of life: the development of a person between childhood and old age. Kaluga: Spiritual knowledge.

Pergamenchik, L. A. (2004). Krizisnaia psikhologiia [Crisis psychology]. Minsk: Vysshaia shkola. [ in Russian]

Pomytkina, L. V. (2017). Pryiniattia rishen yak faktor stresovoi sytuatsii dlia subiekta pratsi v

osoblyvykh umovakh diialnosti / Aviatsiina ta ekstremalna psykholohiia u konteksti

tekhnolohichnykh dosiahnen: zbirnyk naukovykh prats [Acceptance resolution as a factor of stress situation for the sub-act in special minds. Aviation and Extreme Psychology in the context of technological doyagnen: collection of scientific works]. Kiev: Agrar Media Grup, 228232. [in Ukrainian]

Polukhina, M. P. (2017). Psykholohichni osoblyvosti profesiinykh aspektiv pravookhoronnykh orhaniv [Psychological special features of the occupational aspects of law enforcement]. Pravo i bezpeka: naukovyi zhurnal Kharkivskoho natsionalnoho universytetu vnutrishnikh sprav [Right and
Security: Science Magazine]. Kharkiv, 3 (66), 145-149. [in Ukrainian]

Baranenko, B. I., Babichev, D. O., Krivolapchuk, V. O. (Red.). (2012). Psykholohiia bezpeky profesiinoi diialnosti v systemi MVS Ukrainy : navch.-prakt. posib. dlia vyshch. navch. zakl. [Psychology of safety of professional activity in the system of the Ministry of Internal Affairs of Ukraine]. Lugansk: RVV LDUVS. [in Ukrainian]

Simanyuk, E. E. (2004). Psikhologiia professionalno obuslovlennykh krizisov [Psychology of professionally conditioned crises]. Moscow. Voronehz, 29. [in Russian]

Titarenko, T. M. (2004). Kryzovi psykholohichni konsultatsii [Crisis psychological counseling]. Kiev: Glavnik. [in Ukrainian]

Shihi G. (1999). Vozrastnye krizisy [Age crises]. SPb.: Yuventa. [in Russian]

Kokun, O. M., Karpoukhina, A. M. (2010). Psykholohichni osoblyvosti profesiinoho stanovlennia menedzheriv bankivskoi sfery [Specifics of becoming a professional bank manager]. Advances in Cognitive Ergonomics. Boca Raton: CRC Press, 693-706. [in Ukrainian]

Polukhina, M. (2017). The problem of the crisis of professional identity formation in the philosophical and psychological sources. Proceedings of III International scientific conference «Modern scientific achievements: experience exchange». Morrisville: Lulu Press, 213-216.

Pomytkina, L. (2016). Subjective analysis of regularities of making strategic life decisions in late adolescence. Fundamental and applied researches in practice of leading scientific schools. Hamilton. 4 (16), 107-116.

Seeger, M. W. (1998). Communication, organization and crisis. Communication Yearbook. (Vol. 21). 231-275.

Venette, S. J. (2003). Risk communication in a High Reliability Organization: APHIS PPQ's inclusion of risk in decision making. Ann Arbor, MI: UMI Proquest Information and Learning. 